\title{
Applying Post-Legislative Scrutiny to the Analysis of Legislation and SDGs in South and Southeast Asia
}

\author{
Franklin De Vrieze \\ Westminster Foundation for Democracy \\ Email: Franklin.DeVrieze@wfd.org \\ Fotios Fitsilis \\ Scientific Service of the Hellenic Parliament \\ Email: fitsilisf@parliament.gr
}

\begin{abstract}
Post-Legislative Scrutiny (PLS) is an emerging oversight technique which is applied by parliaments to scrutinise implementation and impact of specific laws or legal frameworks. This article takes stock of PLS practices in countries in South and Southeast Asia and argues that PLS can also be used to scrutinise complex processes at the national or supra-national level, such as the implementation of the Sustainable Development Goals (SDGs). First, a wide introduction and the state of play in PLS is provided, with reference to different parliamentary and development approaches emerging from the application of PLS in parliaments worldwide, followed by two specific case studies: the law on microfinance in Myanmar and the law on social practice reform in Nepal. The examination of these case studies offers insights about the application of scrutiny techniques in different parliaments. The outcome of the analysis is used to respond to the main research question of this contribution: whether PLS techniques can be applied for the oversight of extended processes, as is the case with the implementation of SDGs. For this, details of the first world study on parliamentary oversight of SDGs are presented, with a regional focus on South and Southeast Asia. The results seem to support the authors' claim that PLS as a technique can facilitate oversight both of specific legal provisions and complex multi-stakeholder processes, such as the monitoring of SDGs.
\end{abstract}

Keywords: Post-legislative Scrutiny, Sustainable Development Goals, Microfinance, Social Practices, Myanmar, Nepal

\section{INTRODUCTION}

In December 2019, the Journal of Southeast Asian Human Rights (JSEAHR) published its first Special Issue on Post-Legislative Scrutiny (PLS). The articles emerged from the presentations at the Academic Conference on Post-Legislative Scrutiny in Asia, which the University of Jember (Indonesia), University of Yangon (Myanmar) and the Westminster Foundation for Democracy (WFD) co-organised in June 2019 in Yangon, bringing together 700 participants from 20 countries from Asia and beyond. One of the presentations during the conference 
Applying Post-Legislative Scrutiny in South and Southeast Asia

analysed the interface between PLS and the Sustainable Development Goals (SDGs), ${ }^{1}$ with the relevant working paper presented during the July 2019 Wroxton Workshop for Parliamentary Scholars and Parliamentarians. ${ }^{2}$ At the core of the underlying study there is an open dataset. The current article in the second JSEAHR thematic issue on PLS brings together those findings with additional analysis on the interface between PLS and SDGs, and legislative cases at the regional level. It hypothesises that the PLS technique can both facilitate oversight of highly specific legal provisions and complex multi-stakeholder processes, such as the monitoring of SDGs. Case studies from the greater South and Southeast Asia region have been selected for this purpose.

The case study on the law on microfinance in Myanmar has been chosen as it is related to poverty reduction, the creation of employment and the generation of income. Simultaneously, these impacts align with the core objectives of the SDGs. Similarly, the law on social practice reform in Nepal was selected as it is related to the regulation and reform of Nepalese social interactions, conditions which are, among others, specifically significant for the position of women in society. These two case studies were prepared by WFD teams in Myanmar and Nepal in early 2020 are based on structured interviews with relevant stakeholders involved in pilot projects currently underway in the national parliaments. ${ }^{3}$ The interviews were conducted with the goal of recording key statements by parliamentary interlocutors or stakeholders, to identify relevant public documents, such as papers, reports, minutes and interviews and to gather both quantitative and qualitative data relevant to the law in question.

Because PLS is a relatively new oversight tool, previously unapplied in the national governance systems of the countries concerned, it was considered prudent to start with a pilot project approach, rather than initiating a ground-breaking institutional reform at the parliamentary level. A pilot project enables the parliaments to try out new approaches of engagement with relevant stakeholders based upon a problem analysis statement discussed and agreed within the relevant committees. Such an approach also facilitates discussions on lessons learned on the functioning of the committees and serves as a monitoring and evaluation tool of parliamentary performance. The pilot projects in the two countries mentioned are ongoing and, upon finalisation, the discussion on institutionalisation of PLS processes in the national parliaments should be further enabled.

The third case study centres on the parliamentary monitoring of SDGs and will display whether PLS can also facilitate oversight of much more complex processes

1 Fotis Fitsilis \& Franklin De Vrieze, How Parliaments Monitor Sustainable Development Goals - A Ground for Application of Post Legislative Scrutiny (Yangon, 2019).

2 Fotios Fitsilis \& Franklin De Vrieze, Parliamentary Oversight of Sustainable Development Goals and the Application of Post-Legislative Scrutiny Principles (Wroxton: Social Science Research Network, 2019).

3 See annex I for a comprehensive list of interviews; the questionnaire from annex II was used during the interviews. 
and legal frameworks. ${ }^{4}$ One needs to underline the responsibilities of parliaments towards successful implementation of the 2030 Agenda. ${ }^{5}$ The pertinent analysis relies on an open dataset created as part of a relevant ongoing study to shed light on the engagement of parliaments in controlling the implementation of SDGs. ${ }^{6}$ The public repository enables open access to all parameters of the study for scientific scrutiny and future updates. The dataset contains different institutional and non-institutional measures from several world parliaments. At the time of the baseline study report (April 2019) the dataset included 154 entries corresponding to 153 member states of the United Nations and Palestine, which enjoys observer status. This case study is based on the analysis of a subset of the original dataset, which includes South and Southeast Asia.

The two-dimensional matrix contains country and geographical data, details on intra and extra-parliamentary conduct, issues regarding control of the SDG budget, and general comments and references. Particular importance was paid to data validation. Thus, whenever possible, multiple data sources for a single data entry have been scrutinised, e.g. voluntary national reports, scientific literature, and reports from international and civil society organisations. When assessing textual data for a global study, inherent limitations need to be taken into consideration, such as foreign languages, use of English, data format etc. ${ }^{7}$

Following the introductory chapter, the relevance of PLS for democratic and effective governance is broadly discussed, highlighting key concepts and application issues (chapter II), before presenting three characteristic case studies: the law on microfinance in Myanmar, the law on social practice reform in Nepal, and the parliamentary monitoring of SDGs in South and Southeast Asia (chapter III). The concluding chapter summarises the most significant results from the analysis, together with a brief outlook (chapter IV).

\section{RELEVANCE OF POST-LEGISLATIVE SCRUTINY}

Post-Legislative Scrutiny (PLS) is usually not considered among traditional parliamentary functions. Nonetheless, in the last few decades, it has generated increased interest among many parliaments worldwide, among others for the way it reshapes the historic notion of key functions of parliament, law making and oversight of the executive. In addition, it can also be considered as a way to upscale parliament's involvement in the evaluation of public policies.

4 Transforming our world: the 2030 Agenda for Sustainable Development, by UNGAOR, UN Doc A/RES/70/1 (2015).

5 The Role of European Parliaments in the Implementation of the 2030 Agenda and the SDGs, Quarterly Report, by Eric Mulholland, Quarterly Report 45 (Vienna: ESDN, 2017).

6 Fotios Fitsilis \& Eleni Zisioglou, Dataset on parliamentary involvement in SDG monitoring (2019).

$7 \quad$ Fotios Fitsilis \& Franklin De Vrieze, "How parliaments monitor sustainable development goals - a ground for application of post legislative scrutiny” (2020) The Journal of Legislative Studies $1-21$. 
Applying Post-Legislative Scrutiny in South and Southeast Asia

The task of monitoring how laws are implemented and the effects they produce is an integral part of a full-cycle approach to law-making. This means that the lawmaking process is not completed by the entry into force of the Act, but also continues at the law implementation stage, which should inform future legislative initiatives. PLS is therefore part of the process of law-making, aimed at improving the quality of the legislative norms. Simultaneously, PLS is part of the oversight function that parliaments exercise with respect to the executive. Oversight means that parliaments attempt to get a clear view over the actions of government, enforce accountability and adopt any necessary measures to safeguard public interests. The engagement of parliaments in PLS is driven by the standard oversight approach aimed at making the executive accountable before parliament.

In this way, PLS can be framed as a parliamentary duty with the specific purpose of supporting parliament's engagement in impact assessment and ex-post evaluation. While these are not always considered as explicit or stand-alone functions of parliament, in the last few decades more parliaments were engaged in ex-post impact assessment and, thus, monitor the implementation of the laws they have passed. PLS refers to the moment in which a parliament asks itself a crucial question: whether the laws of a country are producing expected outcomes, and if not, why? As the UK's Lord Norton argues, "PLS may be seen as a public good", because it is designed to ensure that measures of public policy deliver on what the representatives of the people voted for. It means assessing the consequences against the purposes identified when the measures were introduced.

The UK Law Commission outlined four main reasons to develop more systematic PLS ${ }^{8}$ : to determine whether legislation is working out in practice as intended; to contribute to better regulation (secondary legislation); to improve the focus on the implementation and delivery of policy aims and to identify and disseminate good practise so that lessons may be drawn from the successes and failures revealed by this scrutiny work. In addition, one can mention the need to act preventively regarding potential adverse effects of new legislation on fundamental rights, as well as, for instance, on the environment or on economic and social welfare. By reviewing government action or inaction and by amending legislation of various kinds, a parliament takes measure of the extent to which the laws of a country are fit for purpose, as well as the extent to which a government is managing the effective implementation of its policies and abiding by statutory obligations.

However, this link is not always formally recognised within the parliamentary system and relevant information is not always captured, directed and responded to on that basis. ${ }^{9}$ The act of carrying out PLS can therefore be justified as a stand-alone activity that enables a parliament to self-monitor and evaluate, as well as reflect on the merits of its own democratic output and internal technical ability. Various

Post-Legislative Scrutiny, by The Law Commission, 302 (London: Law Commission, 2006).

According to Philip Norton's opening address at the Academic Seminar on PLS co-organized by WFD and the Institute of Advanced Legal Studies at the University of London, 10 July 2018. 
parliaments, a variety of which are mentioned in this comparative study, are beginning to institutionalise PLS as a separate mechanism within parliament. ${ }^{10}$

There are two dimensions of PLS. It can refer to a broad legislative review, the purpose of which is to evaluate whether and to what extent a piece of legislation has achieved its intended purpose and what its impact is. It can also refer to a narrower evaluation of how a piece of legislation is working in practise. This latter variant is a more legal and technical review. ${ }^{11}$ In consequence, the act of PLS holds two distinct functions: a monitoring function, as the application of legislation and especially the adoption of the necessary secondary legislation is assessed by parliament at identified moments and an evaluation function, as parliaments seek to ensure the normative aims of policies are reflected in the results and effects of legislation. ${ }^{12}$

When conducting PLS, parliament should consider whether the responsibility for it should lie with its standing (permanent) committees or with a dedicated body. In some countries, the standing, thematic oversight committees take a lead role, while in others the lead role is assumed by the legislative committee or a specially created ad-hoc committee. To ensure broad consensus on the findings and recommendations, PLS should be an inclusive process in which all party groups in parliaments are able to participate.

For Parliament to conduct PLS inquiries effectively, it needs to empower its human resources and enable them to work with appropriate ICT systems and applications. Parliament may consider whether to establish a specialised PLS parliamentary section, assign the role to the regular committee staff, or to outsource this function to an external independent review panel that must report to parliament. In-depth engagement and analysis of the functioning of the implementing agency assigned to ensure the implementation of the legislation is a key-part of the PLS inquiry.

Effective PLS requires full and timely access to governmental information, as well as to the views of a wide range of stakeholders, including civil society organisations. Public engagement in PLS enables access to additional sources of information, increases the credibility of the findings, and enhances public trust in democratic institutions. As a PLS inquiry is coming to a close, parliament should have processes in place to ensure consideration of the findings of PLS so that, where necessary, changes to legislation and policy can be made in a timely manner. In the $\mathrm{UK}$, for instance, there is an agreement that any inquiry report by parliament receives a written response by the government within two months, outlining whether the government accepts, rejects or partially accepts the findings and recommendations and the rationale for that. This is a good practice, which ensures that parliamentary recommendations are considered and an institutional dialogue between parliament and government will take place.

10 Norton, "Post-legislative scrutiny in the UK Parliament", supra note 8.

11 Ulrich Karpen, "Good Governance through Transparent Application of the Rule of Law" (2009) 11:2 Eur JL Reform 213.

12 Post-Legislative Scrutiny, by Richard Kelly \& Michael Everett, Parliament and Constitution Centre (London: House of Commons Library, 2013), SN/PC/05232. 
Applying Post-Legislative Scrutiny in South and Southeast Asia

\section{CASE STUDIES}

The following are two country-specific case studies on legislative acts, from Myanmar and Nepal, and a thematic case study on parliamentary monitoring of SDGs in South and Southeast Asia. All case studies include specific sections on context, problem statement, parliamentary processes and a synopsis.

\section{The Law on Microfinance in Myanmar}

The law on microfinance in Myanmar is the subject of the first case study. It relies on a pilot project of the House of Representatives, Pyithu Hluttaw, which is the lower house of the bicameral Assembly of the Union of Myanmar, with the support of WFD.

\section{a. Context}

Microfinance in Myanmar started in the mid-1990s when the government allowed the UNDP Human Development Initiative to begin with its microfinance project. ${ }^{13}$ Since then, international organisations have started implementing microfinance programmes more widely. In a country where a quarter of the population is living under the poverty line $\mathrm{e}^{14}$, microfinance has been regarded as a possible solution to empower Myanmar's poor population by enabling them to invest in small and medium enterprises. In consideration of its potentially great benefits in helping reduce poverty, creating job opportunities, and to generate incomes, Myanmar passed a law on microfinance in 2011 with the primary objectives to alleviate poverty, improve the socio-economic status of the poor, and to encourage the development of small-scale businesses, among others. ${ }^{15}$ Microfinance institutions (MFIs) started operating nationwide as of March 2019. According to official statistics 2,614,017.46 million Myanmar Kyats (MMK) have been issued in credit by 181 MFIs (110 domestic, 47 foreign, 16 NGO, three INGO, five Cooperative) across 1,509,112 borrowers in 142 townships, 1,995 wards, 7154 village tracts, and 22,893 villages. ${ }^{16}$

\section{b. Problem Statement}

13 Microfinance for Poverty Alleviation in Myanmar, Knowledge Management Issue Brief (United Nations Development Programme), by Heinz Willems \& Paul Luchtenburg, Knowledge Management Issue Brief (United Nations Development Programme) (UN Capital Development Fund (UNCDF), 2014).

14 The World Bank, "Poverty Report- Myanmar Living Conditions Survey 2017”, (2019), online: World Bank <https://www.worldbank.org/en/country/myanmar/publication/poverty-reportmyanmar-living-conditions-survey-2017>.

15 The Republic Union of Myanmar, The Microfinance Law (The Pyidaungsu Hluttaw Law No.13, 2011) (The Republic Union of Myanmar, 2011).

16 FRD, "Detailed Information on Microfinance Institutions", (March 2019), online: Financial Regulatory Department <www.frd.gov.mm/?q $=$ my/information>. 
The 2011 law itself is built upon promising objectives and asserts a wide range of functions, responsibilities, and legal obligations to respective actors, such as the dedicated ministerial committees ${ }^{17}$ and microfinance institutions in terms of the formation, license provision, regulatory compliances, and penalties. Regardless of its ambitious objectives and being acknowledged as essential for low-income people, there are, however, substantial drawbacks. These include the inaccessibility of microfinance loans to poor rural populations, the indebtedness of the clients and the overlapping credits due to the lack of a credit monitoring system. ${ }^{18}$ According to a 2018 report, ${ }^{19}$ MFIs reported that there is lack of clarity in the existing regulations. ${ }^{20}$ UNDP also reported that certain areas of regulation limit expansion of credit to priority areas, including the rural and agriculture sectors. ${ }^{21}$ The introduction of new directives, particularly for interest rates without consultation, is also reported to have created adaptability issues for MFIs. ${ }^{22}$ These issues point to the need to review the law on microfinance so that it is more effective for its beneficiaries.

\section{c. Post-Legislative Scrutiny by Parliament}

The WFD first introduced the international best practises of PLS to the Myanmar parliament in early 2017. Since PLS was an entirely new practise for this parliament, WFD provided substantive support by means of detailed guidelines, technical workshops and subject matter experts through each step of the inquiry process of the two subject committees. ${ }^{23}$

In mid-2017, the lower house Committee on Banks and Monetary Development initiated their PLS inquiry on the law on microfinance and invited the Ministry of Planning and Finance and the Financial Regulatory Department to present their own assessment of the law and the challenges in implementing it. The Committee then decided that the law on microfinance and its issues have a substantial impact on low-

17 The 2011 law provides functions and responsibilities to implement the law, to oversight MFIs, and to enforce penalties to the following committees: the Rural Development and Poverty Reduction Working Committee (now dismissed), the Microfinance Supervisory Committee, the Microfinance Business Working Committee, and the Myanmar Microfinance Supervisory Bureau (now replaced by the Financial Regulatory Department)

18 Tadhg Walker, "Microfinance in Myanmar: A Silver Bullet to Stamp out Poverty?", (1 March 2016), online: Consult-Myanmar <https://consult-myanmar.com/2016/03/01/microfinance-inmyanmar-a-silver-bullet-to-stamp-out-poverty/>.

19 Myanmar Financial Report, by Frontier Myanmar (Yangon, 2018).

20 As of January 2020, the Microfinance Supervisory Committee has issued 21 directives and notifications and the Financial Regulatory Department has issued 5 directives and procedures.

$21 \quad$ Willems \& Luchtenburg, supra note 14.

22 Thiha Ko Ko, "Finance ministry cuts microfinance loan interest rates", (11 June 2019), online: The Myanmar Times <https:/www.mmtimes.com/news/finance-ministry-cuts-microfinanceloan-interest-rates.html .

23 These are the Women and Children's Rights Committee in the Upper House and the Banks and Monetary Development Committee in the Lower House. 
Applying Post-Legislative Scrutiny in South and Southeast Asia

income people and require a thorough review. ${ }^{24}$ The inquiry was launched with terms of reference aiming to make primary legislation and by-laws more effective for the people, to amend directives to be consistent with the primary legislation, to promote participation of the parliamentary committee staff in the scrutiny process and to increase their capacity.

Before engaging with external stakeholders, the Committee conducted a legal review of the law, its directives, and orders to identify strengths, weaknesses and limitations. It was followed by a mapping of stakeholders to identify relevant implementing bodies, agencies and beneficiaries to be consulted. Based on these and with subject matter experts' input, the Committee developed structured questions for each stakeholder group and met with the relevant ministerial departments and local authorities, 21 microfinance institutions, and 210 clients in Yangon, Pathein, Mandalay, and Taungoo townships, where microfinance operations are active.

Based on the analysis of their findings, the Committee developed a draft "PostLegislative Scrutiny Report on the Myanmar Microfinance Law 2011", categorising their recommendations into three sections, namely implementation issues, suggested amendments and the need for public awareness raising. Between August 2017 and May 2019, the Committee and the Ministry held 10 rounds of discussions, ${ }^{25}$ before the Ministry finally accepted the suggested amendments to the legislation. The Committee agreed to remove the suggestions for a single section of the law from its report provided that the Ministry submits a new bill incorporating their recommendations. Thus, the Committee submitted their report on the remaining two sections to the lower house in May 2019 and the Ministry started drafting the new microfinance bill in line with the Committee's suggestions. The bill was posted on the website of the Union Assembly of Myanmar on October 16, 2019 for public consultation and sent to the lower house for debate on December 10, 2019. The bill was debated and approved in the lower house on February 5, 2020 and the legislation, by the time of submission of this article, was with the upper house for consideration.

\section{d. Synopsis of Case Study}

The PLS inquiry by Myanmar's lower house Committee on Banks and Monetary Development and the subsequent discussions with the Ministry have accelerated the comprehensive review of the microfinance law and created momentum and political will for new legislation addressing the shortcomings. The new law will address the indebtedness of clients, the sustainability of MFIs and the channels for clients to receive financial knowledge. Furthermore, the bill aims to support rural populations, eliminate illegal loan services and provide financial support to local businesses

24 House of Representative, The Microfinance Law (The Pyidaungsu Hluttaw Law No.13, 2011) (The Republic Union of Myanmar, 2011).

25 Interview with Than Than Hlaing, Assistant Director of the Banking and Monetary Development Committee (March 2020); see also supra note 3. 
involved in agricultural and livestock activities. ${ }^{26}$ According to a local think-tank, the bill provides a stronger role for the government bureaucracy to administer the microfinance sector by reducing the number of committees and the inclusion of clear tasks for the Committee and the department. ${ }^{27}$ The bill also includes provisions that enforce MFIs to provide financial training to the clients ${ }^{28}$ and to address the indebtedness of the clients due to their lack of financial knowledge and business knowhow.

The Myanmar parliament's leadership has expressed its intention to institutionalise and embed pre-legislative and post-legislative practices into parliament's work, building on the lessons learned from the pilot inquiries and international good practice. As there is no systematic PLS use without a serious interest (either in a committee or ministry) or specific issues to resolve, WFD is working with the Myanmar parliament to develop a standardised mechanism for selecting laws to review and how to establish effective Parliament-Government relations.

\section{The Social Practices Reform Act of Nepal}

The next case study is centred on a similar pilot project of the Legislation Management Committee of the Federal Parliament of Nepal, Sanghiya Sansada, with WFD's support. This time, the point of interest for PLS is the decades-old and possibly obsolete Social Practices Reform Act.

\section{a. Context}

In 1976, Nepal enacted the Social Practices Reform Act, which aimed at regulating and reforming social interactions among its population. ${ }^{29}$ The act covers specific social practices that are observed or conducted during the lifespan of a Hindu person. The regulated Hindu practices include:

1. Chhaiti, the birthday to be observed on the sixth day of the birth of a child.

2. Nwaran, the name giving eleven days following the birth of a child.

3. Pasni, the feeding of rice to a child for the first time after birth.

4. Chudakarma, the cutting of the hair of a boy for the first time while leaving a scuff of hair uncut.

26 Myat Thura, "New microfinance bill submitted for approval | The Myanmar Times", Myanmar Times (16 December 2019), online: <https://www.mmtimes.com/news/new-microfinance-billsubmitted-approval.html>.

27 The Ananda, "Bill Analysis: The Microfinance Business Bill", (14 January 2020), online: The $\bar{A}$ nanda <https://theananda.org/en/blog/view/-bill-analysis-microfinance-business-bill>.

28 The Republic Union of Myanmar, "The Microfinance Bill, Pyidaungsu Hluttaw Burmese Version”, (2019), online:

<https://pyidaungsu.hluttaw.mm/uploads/pdf/57wyhr_18.9.2019\%20MFI\%20Law\%20Hluttaw \%20Legal\%20Team.pdf>.

29 Law Commission of Nepal, Social Practices (Reform) Act, 2033, Section 2(a) (1976). 
Applying Post-Legislative Scrutiny in South and Southeast Asia

5. Bratabandha, the marriage ceremony in which a boy wears a sacred thread (janar).

6. Budo-pasni, the practice to be observed by man and women when 48 years old.

7. Pitri-karya, the practice in honour of deceased ancestors.

The Act was introduced at a time when Nepal was under the autocratic royal regime called Panchayat. ${ }^{30}$ While the constitution guaranteed severely limited fundamental rights to all Nepali citizens, the government could impose restrictions on their application for reasons related to the "public good". ${ }^{31}$ At the time of its enactment, the Act's intention was to "impose restriction on existing as well as growing competitive pomp and worthless expenses in social practices in order to make reforms" as stated in the preamble. The Act also seemed to encourage gender equality and to discourage or set limits on traditions that were discriminatory against women, such as the dowry transaction.

For instance, the Act stipulates that no more than 51 persons including neighbours and relatives can be invited to the marriage feast or that maximum 11 persons can play musical instruments in the marriage ceremony of Janta. ${ }^{32}$ It also prohibits the bridegroom from compelling the bride "to give cash, goods, [dowry], donations, gifts, farewell gifts ... in connection with or after marriage." ${ }^{33}$ The likely aim of these provisions was to reduce "extravagant" expenditure on marriage ceremonies and dowry. However, while the law stipulates a maximum ceiling of 10,000 rupees for those who intend to give dowry "as per one's own rites, rituals and pleasure", these clauses also legitimised the continued practice of dowry in Nepal. ${ }^{34}$ It is worth mentioning that the country sees an alarming number of dowry-related physical and psychological harassment of women. ${ }^{35}$

\section{b. Problem Statement}

Over the past 44 years since enactment of the Act, Nepal has seen transformative political, social, and economic changes, such as the restoration of multiparty democracy, the abolition of the monarchy, the establishment of the republic and the transformation from a unitary into a federal State, ${ }^{36}$ during which several legal provisions have become outdated. In the light of the mentioned socio-political changes, there have been previous attempts to change the Act, but without success. For example, in 2017, the Parliament's State Affairs Committee agreed on a proposal

30 Narayan Khadka, "Crisis in Nepal's Partyless Panchayat System: The Case for More Democracy” (1986) 59:3 Pacific Affairs 429-454.

31 Federal Democratic Republic of Nepal, The Constitution of Nepal, 1962, Part 3 (17).

32 Janta has been defined as "a tradition in which a group of people go to the chamber of marriage where ceremony is being observed together with the bridegroom in order to bring the bride in the home of the bridegroom"; see Social Practices (Reform) Act, 2033,1976, at 4.

33 Law Commission of Nepal, Social Practices (Reform) Act, 2033, Section 5(1) (1976).

34 Law Commission of Nepal, Social Practices (Reform) Act, 2033, Section 5(2) (1976).

35 Sanjaya Dhakal, "Nepalese women under the shadow of domestic violence" (2008) 371:9612 The Lancet 547-548.

36 Deepak Thapa, "Introduction" in Politics of Change: Reflections on Contemporary Nepal (Kathmandu: Himal Books for Social Science Baha and The Asia Foundation, 2019) ix. 
to amend ${ }^{37}$ the Act, but the Parliament was dissolved before the Committee had a chance to table it in the legislature.

The attempts to change these provisions were guided by the widespread nonobservation of the Act, occurring for several reasons, such as improvement in the spending power of Nepalese citizens or the more relaxed attitude of authorities in substantive enforcement. the nature and visibility of debates in Nepali public discourse, ${ }^{38}$ including media articles ${ }^{39}$ and official reports by the Nepal Law Commission ${ }^{40}$ and the Home Ministry, ${ }^{41}$ suggest that this Act is neither implemented nor complied with by the public. As provisions have been flouted openly, many were raising questions on the utility of the Act, stating that its purpose has been defeated entirely. ${ }^{42}$

The Home Ministry report, while recognising that people have flouted those provisions, also notes that in the absence of complaints filed, no actions have been taken. As Nepali society underwent transformative changes, including "remarkable progress on improving living standards and reducing poverty," 43 festivities have become bigger and more expensive, which is also due to the expansion of the urban population, with organisers inviting hundreds of people. ${ }^{44}$ Moreover, the Law Commission report stated that provisions of at least 12 clauses of the Act "haven't been in full sync with social practice and tradition" and that "society hasn't abided by the provisions since the Act was promulgated.” ${ }^{45}$

\section{c. Post-Legislative Scrutiny by Parliament}

Against this background, the Legislation Management Committee of the National Assembly of the Federal Parliament of Nepal conducted between 2019 and 2020 its first-ever PLS inquiry of the 1976 Social Practices Reform Act. Committee officials ${ }^{46}$ highlighted that the Committee had selected this Act for a pilot PLS inquiry as it is a

37 The Himalayan Times, "SAC endorses Social Practices Reform Bill", The Himalayan Times (27 March 2017), online: <https://thehimalayantimes.com/kathmandu/state-affairs-committeeof-the-parliament-endorses-social-practices-reform-bill/>.

38 Manoj Satyal, "Inviting 150 to Janta and 350 to Feast will be Allowed”, (30 July 2014), online: PahiloPost<https://pahilopost.com/content/-119.html>.

39 Radheshyam Khatiwada, "Violation of law during weddings and parties", (22 July 2018), online: Ujyaalo Online <https://ujyaaloonline.com/story/3114>.

40 A study on the current situation of the implementation of the Social Practices (Reform) Act 2033, by Law Commission of Nepal (Kathmandu: Nepal Law Commission, 2019).

41 The Home Ministry, "Opinion related to reform of the Social Practices (Reform) Act 2033", The Home Ministry (2019).

42 Law Commission of Nepal, supra note 41.

43 Moving up the ladder: Poverty reduction and social mobility in Nepal, by Sailesh Tiwari, documents.worldbank.org, 106652 (Washington, DC: The World Bank, 2016).

44 Khatiwada, supra note 40.

45 Law Commission of Nepal, supra note 41.

46 Personal communication with Hon. Parsu Ram Meghi Gurung, Chairperson, Legislation Management Committee (May 2019 to March 2020). 
straightforward law, which is impacting the lives of $81.3 \%$ of the country's population, who are Hindus. ${ }^{47}$

The Committee has the mandate to manage legislation and conduct studies, inquiries and assessment of implementation of laws. The Committee chairperson recognised that to protect the rule of law, any active law must be known to people and that for any law to be implemented or enforced it should accurately, or to a reasonable extent, reflect the realities of the society for which it is crafted. Therefore, the Committee decided to measure the impact of the Act with the aim to encourage amending its main provisions to reflect the socio-economic and political changes in the country. In its upcoming PLS report, the Committee is expected to recommend an overhaul of the Act, keeping in mind the recommendation of the Nepal Law Commission that a new law be formulated to replace the existing Act because it would be impossible to address the majority of the outdated provisions by amendments alone. $^{48}$

By the time of article submission, the Committee was yet to formally consider its recommendations. However, the following issues are currently under consideration $^{49}$ :

1. The Act needs to be either drastically amended or replaced by a new well drafted law.

2. Secondary legislation needs to be brought out accordingly.

3. Additional financial or human resources needs to be allocated for implementation of the law.

4. New policies need to be formulated with regards to the topic addressed by the law.

5. There is a need to create awareness among the public about the substance of the law.

6. There is a need for further research on some aspects related to the implementation of the law.

Reflecting on the relevance of this PLS inquiry for the functioning of the Parliament of Nepal, it is worth noting that the Committee took a highly systematic and methodological approach to preparations for its PLS inquiry. The Committee first educated itself on the topic and the concept of PLS through a nation-wide workshop engaging various experts, including those from the Nepal Law Commission, WFD, the UK House of Commons, and former Nepali MPs. In 2019, Committee members and parliamentary employees attended an international PLS conference in Myanmar, where they interacted with experts and legislators from around the world.

$47 \quad$ National Population and Housing Census 2011, National Report, by Central Bureau of Statistics, National Report (Kathmandu: Central Bureau of Statistics, 2012).

48 Law Commission of Nepal, supra note 41.

49 Personal communication, supra note 47. 
The Committee also met to discuss and learn in detail about the various steps of PLS. ${ }^{50}$ They also established a research centre and hired experts to steer the relevant process. It methodologically sequenced its activities, such as the announcement of the inquiry, collection of feedback, conducting a town hall meeting and the organising of a public hearing. The chairperson of the Legislation Management Committee prioritised the production of a document detailing the process and steps involved in the pilot PLS project involving the Social Practices (Reform) Act.

\section{d. Synopsis of Case Study}

The first PLS report in Nepal is expected to contribute to achieving greater gender equality in Nepali society by recommending provisions that would aim to end discriminatory practices against women. That document is also expected to serve as a best practice guide for the Parliament at large and any other committees that may wish to conduct a PLS inquiry in future. It would be interesting to see if a single Committee report will be impactful enough to change age-old discriminatory practices. Nevertheless, there is little doubt that it will be a significant voice of reform.

\section{Parliamentary Oversight of Sustainable Development Goals}

This third case study investigates the potential role of PLS in regard to the monitoring of Sustainable Development Goals. It discusses the nature of parliamentary involvement in SDGs, as described by a relevant world study, with a particular focus on South and Southeast Asia.

\section{a. Context}

Between 2017 and 2019, the "foresight and innovation lab", a distributed entity guided by the Department of Scientific Documentation and Supervision within the Scientific Service of the Hellenic Parliament, conducted the first comprehensive world study on the monitoring of SDGs by parliaments. The study investigated the extent of involvement of national parliaments in the monitoring of SDGs. More specifically, an intra and extra-parliamentary stakeholder analysis has been conducted and the correlation of several study parameters, including geography, monitoring level, stakeholder cooperation, and budgetary allocation within the scrutiny process was discussed. ${ }^{51}$

In total, $153 \mathrm{UN}$ member states appear in the study, among them 41 , or $26.8 \%$ from Asia. Among its most significant results, one may observe that 64 countries, or $41.8 \%$ of the population of the study ( $\mathrm{N}=153)$, demonstrates parliamentary involvement in SGDs of some sort. ${ }^{52}$ Compared to the global trend, Asia, which counts 14 countries with parliamentary

50 Franklin De Vrieze, Post-Legislative Scrutiny: Guide for Parliaments (London: Westminster Foundation for Democracy, 2017).

$51 \quad$ Fitsilis \& De Vrieze, supra note 7.

52 Parliamentary involvement may take different forms, such as parliamentary (sub-)committee, task force, MP network, multi-stakeholder dialogue process, and many more. 
involvement, or constituting $21.9 \%$ of the total, is underperforming. Most interestingly, on the global scale, half of these countries, that is 32 out of 64 , have established dedicated parliamentary bodies for the monitoring of SDG implementation at the national level. Since such parliamentary interventions are linked to the allocation of significant resources, it is reasonable to assume that the political systems attribute political significance and possibly also expect increased efficiency from the monitoring process. For this case study, the underlying dataset has been narrowed down to involve only the countries from South and Southeast Asia.

\section{b. Problem Statement}

Based on the mentioned original data set, the relevant sample population in Asia is $N^{\prime}=41$. From these, eight countries belong to South Asia, ${ }^{53}$ while 10 belong to Southeast Asia and, hence, $N "=18 .{ }^{54}$ In effect, the region under focus represents $43.9 \%$ of N'. When one measures parliamentary involvement, it is found that nine out of 18 countries ( $\left.\mathrm{N}^{\prime \prime}\right)$ display any type of involvement regarding SDGs. What is even more interesting, though, is the finding that seven out of these 18 countries (38.9\%) have formed special bodies dedicated to the scrutiny of SDGs, which outmatches every other regional or continental agglomeration of countries. As a direct comparison, second-best Europe displays a relevant percentage of 31.3\%. A clear explanation for this extraordinary result, i.e. why so many South and Southeast Asian countries are setting up additional working bodies and services to monitor implementation of SDGs, is not imminently at hand. A possible answer though could originate in the frequent and intense regional cooperation, ${ }^{55}$ which might have led to mimic effects among parliaments.

\begin{tabular}{|l|l|c|c|c|}
\hline Country & Geography & $\begin{array}{l}\text { Committ } \\
\text { ee }\end{array}$ & $\begin{array}{l}\text { Sub- } \\
\text { Committee }\end{array}$ & Task Force \\
\hline Bangladesh & South Asia & & $\bullet$ & \\
\hline India & South Asia & & & $\bullet$ \\
\hline Nepal & South Asia & $\bullet$ & & \\
\hline Pakistan & South Asia & & & $\bullet$ \\
\hline Sri Lanka & South Asia & $\bullet$ & & \\
\hline
\end{tabular}

53 The South Asian countries are: Afghanistan, Bangladesh, Bhutan, India, Maldives, Nepal, Pakistan, and Sri Lanka.

54 The Southeast Asian countries are: Brunei Darussalam, Cambodia, Indonesia, Lao PDR, Malaysia, Philippines, Singapore, Thailand, Timor-Leste, and Viet Nam.

55 This could be determined by the multitude of significant international forums and conferences in the region. See, e.g., 1st, 2nd and 3rd World Parliamentary Forum on Sustainable Development in 2017, 2018 and 2019, respectively, in Indonesia, as well as the already mentioned Academic Conference on Post-Legislative Scrutiny in 2019 in Myanmar. 


\begin{tabular}{|l|l|l|l|l|}
\hline Philippines & Southeast Asia & $\bullet$ & & \\
\hline Thailand & Southeast Asia & & $\bullet$ & \\
\hline
\end{tabular}

\section{Table 1: South and Southeast Asian countries with committees or initiatives dedicated to SDGS}

A deeper analysis of the parliamentary interventions of these countries is presented in Table 1, where it becomes visible that five out of seven countries are located in South Asia, which strengthens the mimic hypothesis. Five countries have opted to create an additional parliamentary committee or sub-committee, ${ }^{56}$ while two of them, India and Pakistan, ${ }^{57}$ use a completely different approach by building dedicated research and expert bodies to strengthen the capacity of the parliamentary service to support committees and parliamentarians. The strengthening of parliamentary administration could be a key issue in supporting parliamentary processes, ${ }^{58}$ such as those related to the monitoring of SDGs, since it could be organised in a timely and efficient manner, e.g. by enhancing capacity in specific sectors of interest. Vice versa, the establishment of new parliamentary committees and sub-committees alone, without integrated or linked support, e.g. through the parliamentary research service, may not have the desired multiplier effects.

Hence, within this context, the necessity of special bodies could be questioned, as there is not enough quantitative data at hand to prove their efficiency, such as increased number of scrutinised laws or different types of parliamentary control. As an example, the Indonesian Parliament has consciously chosen not to form a special working body on SDGs and has entrusted existing standing committees with the task. The necessary guidance and coordination are assumed by the Inter-Parliamentary Cooperation Committee, which has benefited from the relevant PLS resources in the Parliament. This general approach is also favoured by parliaments in the West, for instance in Finland. ${ }^{59}$

Another notable finding is related to extra-parliamentary involvement of parliamentarians in the region..$^{60}$ Data evaluation shows that Bangladesh and Bhutan have established some form of cooperation with the government, while in Afghanistan, India and Nepal MPs take part in a multi-stakeholder dialogue. Combined, $27.8 \%$ of $\mathrm{N}$ " display extra-parliamentary involvement, a result which roughly matches the global trend $(24.8 \%)$. Thus, as the scrutiny of SDGs have

56 At the time of the study, the sub-committee in Bangladesh was still at an inception phase.

57 India has established the so-called Speaker's Research Initiative (SRI), while Pakistan has created a parliamentary task force.

58 Fotios Fitsilis, "Inter-parliamentary cooperation and its administrators" (2018) 10:3 Perspectives on Federalism 28-55.

$59 \quad$ Fitsilis \& De Vrieze, supra note 7.

60 In the mentioned study, extra-parliamentary involvement is having three different facets: cooperation with government, multi-stakeholder dialogue, and participation to external commissions. 
Applying Post-Legislative Scrutiny in South and Southeast Asia

attracted the interest of parliaments in the region, one needs to examine whether the PLS technique can be applied for achieving the aforementioned desired results and, if affirmative, to which extent?

\section{c. Post-Legislative Scrutiny by Parliament}

In order to respond to the aforementioned questions, they can be rephrased to cover the extent to which PLS principles should be used to facilitate the parliamentary monitoring process. In this regard, it has already been shown that parliamentary monitoring of SDGs principally satisfies at least five of the basic principles of PLS, ${ }^{61}$ namely:

1. Review secondary or delegated legislation together with the primary act (principle 6).

2. Assess cross-cutting issues (principle 7).

3. Assignment to a permanent committee or dedicated body (principle 8).

4. Empowerment of human resources (principle 9).

5. Access to official information and stakeholder cooperation (principle 10).

In the previous sections, it was shown that most of these principles also correspond to the parliamentary situation in South and Southeast Asia vis-à-vis the SDGs. In addition, axiomatically, by monitoring implementation of SDGs parliaments review their impact on society (principle 4). However, the transparency of the selection process (principle 5) must be ensured on a case-by-case basis. Should parliament agree to the use of an integrated PLS technique, one must assume that further three principles relating to parliamentary mandates (principles 1-3) will be followed: parliamentary responsibility, independence, and binding instruments.

Hence, taking into account that the majority of PLS principles can be applied for the scrutiny of SDGs, among which some that are considered critical for a PLS regime, such as the principles referring to the scope (4-6) and the participants (8-10), it can be deducted that this technique can be utilised by parliaments (by those in South and Southeast Asia, too) to set up a structured and efficient scrutiny process.

\section{d. Synopsis of Case Study}

It is possible to use the Post-Legislative Scrutiny technique to advance SDG monitoring by parliaments. This is true, because the technique can be broken down to a collection of basic principles. These are well-suited to follow-up on the progress of SDGs, since their majority is well within the procedural framework that is already used by several parliaments for the purpose. As a result, those parliaments could more easily adapt to the establishment of a full PLS process. Once there, parliaments could use the momentum to amend, advance the quality of and scrutinise existing

61 See Fitsilis \& De Vrieze, supra note 7, in conjunction with Franklin De Vrieze, Principles of Post-Legislative Scrutiny by Parliaments (London: Westminster Foundation for Democracy, 2017) at 3. 
primary and secondary legislation, and exercise advanced forms of parliamentary control. In addition, the relevant parliamentary actors could use the enhanced visibility and cooperation with stakeholders to further address and localise SDGrelated issues.

\section{CONCLUSION}

The article discussed Post-Legislative Scrutiny at different levels of complexity using three case studies. Two of them are on-going pilot projects dedicated to the scrutiny of specific national legislation, in Myanmar and Nepal, with a third studying the broader concept of parliamentary monitoring of SDGs in South and Southeast Asia.

In Myanmar, the implementation of the law on microfinance has been successfully scrutinised. Following PLS procedures, the relevant Committee on Banks and Monetary Development conducted a full legal review and an external stakeholder mapping. The structured process to amend the law led to 10 rounds of discussion between the Committee and the Ministry. In May 2019, the Committee submitted its PLS report to the lower house. Consequently, the Ministry submitted a new bill in December 2019, which was approved by the lower house in February 2020 .

In Nepal, PLS inquiry has been conducted on the Social Practices Reform Act by the Legislation Management Committee. The Committee followed a systematic approach by first studying the Act and its implications for society in detail. External experts have then been engaged and feedback from external stakeholders has been collected, among others, through a public hearing. While the PLS report is being prepared, a suggestion for a complete overhaul of the Act is expected, which would be in line with prior recommendations by the Nepal Law Commission.

Finally, based on an open data set, parliamentary involvement in the monitoring of Sustainable Development Goals in South and Southeast Asia has been presented and discussed. A total of 18 countries from the region have been represented in the study, with half of them displaying different levels of involvement (50\%), while seven (38.9\%) have even established dedicated bodies for the purpose. This overproportional response is attributed to a mimic effect, though further research is necessary to confirm this hypothesis. In line with previous research findings, the monitoring procedures used by regional parliaments for the oversight of SDGs were revealed to have a lot in common with PLS principles. Hence, the authors see the original hypothesis that the PLS technique can both facilitate oversight of highly specific legal provisions, such as in the two national case studies, as well as of much more complex processes and legal frameworks, such the ones needed for the implementation of SDGs, as widely proven.

As PLS is a broad concept, the case studies demonstrate that it can be differentially conceptualised by varying parliaments and stakeholders. In a narrow interpretation, PLS looks at the enactment of the law, whether the legal provisions of the law have been brought into force, how courts have interpreted the law, and how legal practitioners and citizens have used the law. In a broader sense, PLS looks at 
the impact of legislation; whether the intended policy objectives of the law have been met, as well as the degree of its efficiency. On-going research demonstrates how different parliaments put more emphasis on one or the other of the two dimensions of PLS: to evaluate the technical entrance into force and the enactment of a piece of legislation and to evaluate its relationship with intended policy outcomes and impact. The authors therefore conclude that, to the extent that parliaments seek to carry out both dimensions, PLS facilitates continuous improvement of the law itself and policy implementation. PLS, thus, contributes to increased governance effectiveness and accountability.

\section{BIBLIOGRAPHY}

De Vrieze, Franklin. Post-Legislative Scrutiny: Guide for Parliaments (London: Westminster Foundation for Democracy, 2017).

Dhakal, Sanjaya. "Nepalese women under the shadow of domestic violence" (2008) 371:9612 The Lancet 547-548.

Fitsilis, Fotios. "Inter-parliamentary cooperation and its administrators" (2018) 10:3 Perspectives on Federalism 28-55.

Fitsilis, Fotios \& Franklin De Vrieze. "How parliaments monitor sustainable development goals - a ground for application of post legislative scrutiny" (2020) The Journal of Legislative Studies 1-21.

Karpen, Ulrich. "Good Governance through Transparent Application of the Rule of Law” (2009) 11:2 Eur JL Reform 213.

Khadka, Narayan. "Crisis in Nepal's Partyless Panchayat System: The Case for More Democracy” (1986) 59:3 Pacific Affairs 429-454.

Norton, Philip. "Post-legislative scrutiny in the UK Parliament: adding value" (2019) 25:3 The Journal of Legislative Studies 340-357.

Thapa, Deepak. "Introduction" in Politics of Change: Reflections on Contemporary Nepal (Kathmandu: Himal Books for Social Science Baha and The Asia Foundation, 2019) ix.

The Himalayan Times. "SAC endorses Social Practices Reform Bill", The Himalayan Times (27 March 2017), online: <https://thehimalayantimes.com/kathmandu/state-affairs-committee-of-theparliament-endorses-social-practices-reform-bill/>.

The Home Ministry. "Opinion related to reform of the Social Practices (Reform) Act 2033”, The Home Ministry (2019). 
Thura, Myat. "New microfinance bill submitted for approval | The Myanmar Times", Myanmar Times (16 December 2019), online: <https://www.mmtimes.com/news/new-microfinance-bill-submittedapproval.html>.

Central Bureau of Statistics. National Population and Housing Census 2011, National Report, by Central Bureau of Statistics, National Report (Kathmandu: Central Bureau of Statistics, 2012).

Federal Democratic Republic of Nepal. The Constitution of Nepal, 1962, Part 3 (17).

Fitsilis, Fotios \& Franklin De Vrieze. Parliamentary Oversight of Sustainable Development Goals and the Application of Post-Legislative Scrutiny Principles (Wroxton: Social Science Research Network, 2019).

Fitsilis, Fotios \& Eleni Zisioglou. Dataset on parliamentary involvement in SDG monitoring (2019).

Fitsilis, Fotis \& Franklin De Vrieze. How Parliaments Monitor Sustainable Development Goals - A Ground for Application of Post Legislative Scrutiny (Yangon, 2019).

FRD. "Detailed Information on Microfinance Institutions", (March 2019), online: Financial Regulatory Department <www.frd.gov.mm/ ${ }^{\mathrm{q}} \mathrm{q}=\mathrm{my} /$ information>.

Frontier Myanmar. Myanmar Financial Report, by Frontier Myanmar (Yangon, 2018).

House of Representative. The Microfinance Law (The Pyidaungsu Hluttaw Law No.13, 2011) (The Republic Union of Myanmar, 2011).

Kelly, Richard \& Michael Everett. Post-Legislative Scrutiny, by Richard Kelly \& Michael Everett, Parliament and Constitution Centre (London: House of Commons Library, 2013).

Khatiwada, Radheshyam. "Violation of law during weddings and parties", (22 July 2018), online: Ujyaalo Online <https://ujyaaloonline.com/story/3114>.

Ko Ko, Thiha. "Finance ministry cuts microfinance loan interest rates", (11 June 2019), online: The Myanmar Times <https://www.mmtimes.com/news/financeministry-cuts-microfinance-loan-interest-rates.html $>$.

Law Commission of Nepal. Social Practices (Reform) Act, 2033, Section 2(a) (1976).

-. Social Practices (Reform) Act, 2033, Section 5(1) (1976).

—. Social Practices (Reform) Act, 2033, Section 5(2) (1976). 
Applying Post-Legislative Scrutiny in South and Southeast Asia

Law Commission of Nepal. A study on the current situation of the implementation of the Social Practices (Reform) Act 2033, by Law Commission of Nepal (Kathmandu: Nepal Law Commission, 2019).

Mulholland, Eric. The Role of European Parliaments in the Implementation of the 2030 Agenda and the SDGs, Quarterly Report, by Eric Mulholland, Quarterly Report 45 (Vienna: ESDN, 2017).

Satyal, Manoj. "Inviting 150 to Janta and 350 to Feast will be Allowed”, (30 July 2014), online: PahiloPost<https://pahilopost.com/content/-119.html>.

The Ananda. "Bill Analysis: The Microfinance Business Bill”, (14 January 2020), online: The Ānanda <https://theananda.org/en/blog/view/-bill-analysismicrofinance-business-bill>.

The Law Commission. Post-Legislative Scrutiny, by The Law Commission, 302 (London: Law Commission, 2006).

The Republic Union of Myanmar. "The Microfinance Bill, Pyidaungsu Hluttaw Burmese Version”, (2019), online: <https:/pyidaungsu.hluttaw.mm/uploads/pdf/57wyhr_18.9.2019\%20MFI\%20L aw\%20Hluttaw\%20Legal\%20Team.pdf>.

- The Microfinance Law (The Pyidaungsu Hluttaw Law No.13, 2011) (The Republic Union of Myanmar, 2011).

The World Bank. "Poverty Report- Myanmar Living Conditions Survey 2017", (2019), online: World Bank <https:/www.worldbank.org/en/ country/myanmar/publication/poverty-report-myanmar-living-conditionssurvey-2017>.

Tiwari, Sailesh. Moving up the ladder: Poverty reduction and social mobility in Nepal, by Sailesh Tiwari, documents.worldbank.org, 106652 (Washington, DC: The World Bank, 2016).

UN Statistics Division. "Standard Country or Area Codes for Statistics Use”, (1999), online: <https://unstats.un.org/unsd/methodology/m49/>.

UNGAOR. Transforming our world: the 2030 Agenda for Sustainable Development, by UNGAOR, UN Doc A/RES/70/1 (2015).

Walker, Tadhg. "Microfinance in Myanmar: A Silver Bullet to Stamp out Poverty?", (1 March 2016), online: Consult-Myanmar <https://consultmyanmar.com/2016/03/01/microfinance-in-myanmar-a-silver-bullet-to-stampout-poverty/>.

Willems, Heinz \& Paul Luchtenburg. Microfinance for Poverty Alleviation in Myanmar, Knowledge Management Issue Brief (United Nations Development 
Programme), by Heinz Willems \& Paul Luchtenburg, Knowledge Management Issue Brief (United Nations Development Programme) (UN Capital Development Fund (UNCDF), 2014).

ANNEX I - List of Interviewees and Contributors

1. Than Than Hlaing, Assistant Director, Banks and Monetary Development Committee, House of Representatives (Pyithu Hluttaw), Myanmar

2. Khin San Hlaing, Chair, Banks and Monetary Development Committee, House of Representatives (Pyithu Hluttaw), Myanmar

3. Tin Tun Naing, Secretary, Banks and Monetary Development Committee, House of Representatives (Pyithu Hluttaw), Myanmar

4. Hon. Parsu Ram Meghi Gurung, Chairperson, Legislative Management Committee, Federal Parliament of Nepal

5. Sao Siri Rupa, Country representative, Myanmar, WFD

6. Mar Gay Htoo, Research Associate, Myanmar, WFD

7. Dinesh Wagle, Country representative, Nepal, WFD

8. David Thirlby, Senior Programme Manager Asia, WFD

9. Joel Gateretse, Senior Monitoring, Evaluation and Learning Manager, WFD

10. Graeme Ramshaw, Research and Evaluation Director, WFD

ANNEX II - Questionnaire

1. For the given law, what was the initial problem statement related to PLS?

- What issues did the parliament/committee set out to address by conducting the PLS inquiry?

- What issues were most prominent in the terms of reference for this PLS inquiry or in the opening statements by the committee chairperson?

- Was reference made to SDGs as a relevant policy framework for this PLS inquiry?

2. What process did the parliament/committee follow in conducting the PLS inquiry and its follow-up?

- Did the committee encounter any challenges and why?

3. What are the main issues raised by stakeholders during the inquiry on the implementation of the identified piece of legislation?

4. How did the committee address these issues as brought forward by the stakeholders?

- Were these issues addressed in the final committee report?

- Were recommendations adopted relative to the issues raised by the stakeholders?

5. Can you analyse the content of the PLS recommendations: what type of recommendations did the committee adopt? 
Applying Post-Legislative Scrutiny in South and Southeast Asia

6. Did the recommendations of the committee have any traction within the wider parliament, with ministries, with stakeholders and professional groups, or with the wider public?

7. Has there been any change or impact in the current state of play of the policy debate on this issue? Can one see some wider change at a policy or impact level?

8. How have the beneficiaries of the law benefitted from the PLS inquiry or the broader policy debate emerging from the PLS inquiry?

9. In what way has the PLS inquiry influenced the functioning of parliament?

- Is there an interest for further PLS work on other laws within other committees?

10. Has the PLS inquiry enabled further consideration of the institutionalisation of PLS in parliament, possibly regarding adjustments to structures, resources or procedures of parliament?

Franklin De Vrieze is the Senior Governance Adviser at the Westminster Foundation for Democracy (WFD). He offers programme quality assurance and parliamentary advice to WFD country teams. He conducts research on new and innovative themes for parliamentary programming. He is WFD's in-house expert on Post-Legislative Scrutiny, independent oversight institutions, financial accountability, and anti-corruption. Franklin De Vrieze has worked on governance issues for 20 years. He has been leading parliamentary identification, formulation and evaluation missions. He is author of several academic and policy publications.

Fotios Fitsilis has an academic background in law, economics, and engineering. While operating on a global scale, he has been active in various fields, from telecommunications and logistics, to management and governance. Since 2008, he has been a researcher at the Scientific Service of the Hellenic Parliament. Dr. Fitsilis is teaching at the National School of Public Administration and Local Government, Athens, and has been visiting Professor at the Universidad Complutense de Madrid. In 2017, he founded the Hellenic OCR Team, a crowd-sourcing initiative for the study of parliamentary data. 